\title{
False negative DNA PCR test for JC Virus in Cerebrospinal Fluid Resulting in Delayed Diagnosis of Progressive Multifocal Leukoencephalopathy
}

\author{
Saketh Palasamudram Shekarr ${ }^{1}$, Jeevna Kaur ${ }^{2}$ and Tanmay Parekh ${ }^{3}$ \\ ${ }^{1}$ Department of Pulmonary and Critical care medicine, USA \\ ${ }^{2}$ Department of Internal Medicine, USA \\ ${ }^{3}$ Department of Neurology, USA \\ Submission: November 22, 2018; Published: January 08, 2019 \\ *Corresponding author: Saketh Palasamudram Shekar, Department of Pulmonary and Critical care medicine, Florida, USA
}

\begin{abstract}
Progressive Multifocal Leukoencephalopathy is a rare disease of the Central Nervous System (CNS) caused by reactivation of the JC polyomavirus in an immunocompromised host. It carries a poor prognosis and high mortality rate. Gold standard for diagnosis is brain biopsy however the initial recommend step is to secure diagnosis with PCR showing JC virus in CSF. If negative, PCR is again repeated before attempting brain biopsy as it is the more invasive approach. There have been incidences of delayed diagnosis due to false negative CSF PCR results for JC virus. Here, we present such a case: a 73-year-old man with a recent diagnosis of Chronic Lymphocytic Leukemia on Ibrutinib therapy) who presented with worsening mentation and focal motor deficits. Work up included multiple MRI images of the brain, which demonstrated scattered foci of white matter lesions, with some lesions demonstrating hyperintense Diffusion Weighted Imaging (DWI) signal. Two lumbar punctures were performed, which were negative for infectious etiology (JC Virus negative) and yielded negative cytology. Further workup was negative for drug toxicity, infective endocarditis, primary CNS lymphoma, and primary vasculitis. Brain biopsy was ultimately performed, which demonstrated chronic active viral encephalitis, positive for SV40 by immunohistochemistry consistent with progressive multifocal leukoencephalopathy. This case highlights the importance of obtaining brain biopsy for diagnosis of PML despite negative PCR results for JC virus in CSF, if clinical suspicion remains high.
\end{abstract}

Keywords: JC Virus; PML; Polyomavirus; PCR; False negative; CLL

Abbrevations: DWI: Diffusion Weighted Imaging; CNS: Central Nervous System; CSF: Cerebrospinal Fluid; CLL: Chronic Lymphocytic Leukemia

\section{Introduction}

Progressive Multifocal Leukoencephalopathy (PML) is a rare demyelinating disease of the Central Nervous System (CNS) caused by JC polyomavirus (JC virus). This disease almost entirely occurs in immunocompromised patients resulting in reactivation of latent JC virus causing lytic infection of oligodendrocytes [1]. It commonly involves the cortical white matter of the frontal and parieto-occipital lobes but can involve any part of the brain [2] and is associated with a high mortality rate. Median survival in non-HIV patients is three months [3] and therefore timely diagnosis is crucial. Current guidelines recommend diagnosis be confirmed by PCR for JC virus in Cerebrospinal Fluid (CSF), if neuroimaging is consistent with PML. Brain biopsy still remains the gold standard for diagnosis [4] although it is not explored enough due to invasive nature of the testing. We present a case of PML where the workup demonstrated negative PCR results for
JC virus from CSF obtained on two separate occasions, with the diagnosis ultimately being confirmed with brain biopsy.

\section{Case Report}

73-year-old righthanded male with medical history of Chronic Lymphocytic Leukemia (CLL) on Ibrutinib therapy daily started few months earlier. Other medical history included chronic kidney disease stage III, IgG lambda monoclonal gammopathy, bilateral hearing loss, and polymyalgia rheumatica. Patient was evaluated during a routine visit with outpatient oncology with complaints of increasing fatigue, poor appetite and episodes of incoherence. Additionally, patient felt as if his mental capabilities were diminished including decrease in activities of daily living. During this time, he also developed weakness of the left upper extremity, most noticeable in the hand. Patient, however denied 


\section{Open Access Journal of Neurology \& Neurosurgery}

headache, visual changes, abnormal speech, numbness, nausea, vomiting or fevers.

Neurological exam was significant for inability to perform simple tasks such as spelling 'WORLD' backwards and the ability to recall three words. Motor strength was $4 / 5$ in the upper extremities bilaterally, and 5/5 in the lower extremities. Reflexes were 2/4 and symmetric. Babinski was flexor bilaterally. There was a left side pronator drift and gait exam demonstrated unsteadiness with a stooped posture.

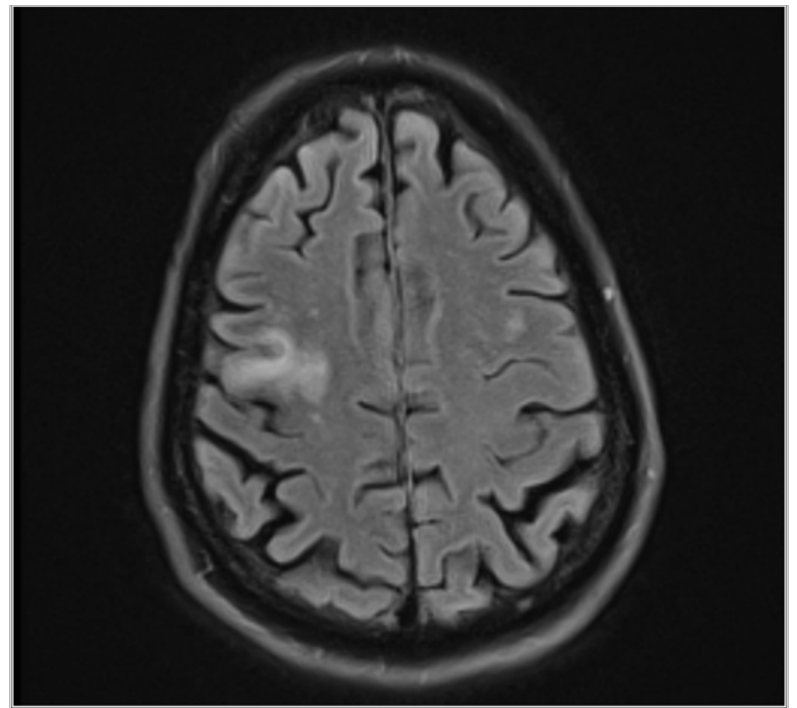

Figure 1: Region of abnormal FLAIR signal involving the posterior right frontal lobe. A smaller but similar-appearing lesion is seen within the left frontal lobe. Also seen are multiple scattered foci of abnormal FLAIR signal seen throughout the brain.

Initial MRI brain showed multiple scattered foci of white matter lesions, the largest of which measured $3.5 \mathrm{~cm}$ involving the right posterior frontal juxtacortical and subcortical white matter (Figure 1). Laboratory studies revealed normal complete blood counts with elevated sedimentation rate of $92 \mathrm{~mm} / \mathrm{hr}$. Ibrutinib was held and patient was admitted to hospital for further workup. Differential diagnosis based on the MRI findings of hyperintense DWI signal changes resembling ischemic lesions included ruling out embolic strokes in an immunocompromised patient with possible underlying endocarditis versus a primary CNS vasculitis. Leukemia, primary CNS lymphoma, and underlying infectious etiology were also high on the differential [2]. Ultimately, work up for the above were negative. HIV testing, Transesophageal echocardiogram were subsequently negative. Two spinal taps were performed during the course of the work up with initial cerebrospinal fluid analysis demonstrated WBC count 2 cells/ $\mu$ l, Protein $51 \mathrm{mg} / \mathrm{dl}$, Glucose $70 \mathrm{mg} / \mathrm{dl}$, and RBC 2 cells/ $\mu$ l with negative cytology. Repeat LP performed few days later demonstrated a WBC 4 cells/ $\mu \mathrm{l}$, Protein $55 \mathrm{mg} / \mathrm{dl}$, Glucose $55 \mathrm{mg} / \mathrm{dl}$, and RBC $1 \mathrm{cell} / \mu \mathrm{l}$ with negative cytology as well.
Both samples were sent out for EBV, CMV, Herpes simplex virus, Enterovirus, VDRL, Lyme, Cryptococcal, VZV, and JC virus by PCR and were reported negative.

Repeat MRI Brain revealed worsening flair signal abnormality involving the right frontal lobe lesion measuring 3.2 $\mathrm{x} 2.8 \mathrm{~cm}$ which was an increase from $3.0 \times 2.0 \mathrm{~cm}$. The number of scattered enhancing foci had significantly decreased compared to prior study. Family reported that patient had started to become frequently agitated, disoriented, and paranoid. Right frontal lobe brain lesion biopsy was then performed which showed chronic active viral encephalitis, positive for SV40 by immunohistochemistry, consistent with progressive multifocal leukoencephalopathy. Patient was started on Mefloquine $250 \mathrm{mg}$ once daily and Mirtazapine $15 \mathrm{mg}$ once daily, but prognosis was ultimately poor.

\section{Discussion}

PML is a rare disease known to predominantly affect immunocompromised hosts such as those with HIV, lymphomas, transplant recipients, and those patients on treatment with monoclonal antibodies. It is a progressive disease with high mortality rate and generally poor prognosis once diagnosed [3]. Diagnosis is usually confirmed by PCR of CSF or by CNS tissue biopsy [4]. Although brain biopsy is the gold standard, guidelines typically recommend establishing diagnosis with PCR first. If negative, physicians are recommended to repeat a spinal tap and PCR testing. At this point, in the setting of high clinical suspicion, a brain biopsy is warranted. Other possible etiologies, such as lymphomas, infectious etiologies such as endocarditis, primary CNS vasculitis, and drug toxicity must be ruled out.

There have been reports of false negative PCR results for JC virus in the CSF, which have lead to delays in diagnosis [5]. This was evidenced by the case presented here. These instances could possibly be attributed to low titers of JC virus DNA in the CSF. As such, despite negative CSF PCR studies, a brain biopsy must be obtained in a timely manner if there is a high clinical suspicion for JC virus. Although overall prognosis is poor, early diagnosis of PML can potentially improve survival in certain patients if immunosuppression can be lifted [6].

\section{Conflict of Interest}

There is no conflict of interest to disclose.

\section{References}

1. Tan CS, Koralnik IJ (2010) Progressive multifocal leukoencephalopathy and other disorders caused by JC virus: clinical features and pathogenesis. Lancet Neurol 9(4): 425-437.

2. Sahraian MA, Radue EW, Eshaghi A (2012) Progressive multifocal leukoencephalopathy: a review of the neuroimaging features and differential diagnosis. Eur J Neurol 19(8): 1060-1069.

3. Koralnik IJ (2006) Progressive multifocal leukoencephalopathy revisited: Has the disease outgrown its name? Ann Neurol 60(2): 162167. 
4. Berger JR, Aksamit AJ, Clifford DB, Davis L, Koralnik IJ, et al. (2013) PML diagnostic criteria: consensus statement from the AAN Neuroinfectious Disease Section. Neurology 80(15): 1430-1438.

5. Marie L Landry, Tore Eid, Serguei Bannykh, Eugene Major (2008) False negative PCR despite high levels of JC virus DNA in spinal fluid: Implications for diagnostic testing. J Clin Virol 43(2): 247-249.
6. Miskin DP, Ngo LH, Koralnik IJ (2016) Diagnostic delay in progressive multifocal leukoencephalopathy. Ann Clin Transl Neurol 3(5): 386-391.

This work is licensed under Creative Commons Attribution 4.0 Licens

DOI: 10.19080/OAJNN.2019.09.555765

Your next submission with Juniper Publishers will reach you the below assets

- Quality Editorial service

- Swift Peer Review

- Reprints availability

- E-prints Service

- Manuscript Podcast for convenient understanding

- Global attainment for your research

- Manuscript accessibility in different formats

( Pdf, E-pub, Full Text, Audio)

- Unceasing customer service

Track the below URL for one-step submission https://juniperpublishers.com/online-submission.php 